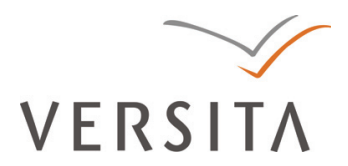

Folia Oeconomica Stetinensia

DOI: $10.2478 / \mathrm{v} 10031-012-0026-5$

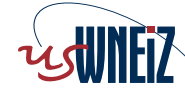

Wydzial Nauk Ekonomicznych i Zarządzania

Uniwersytetu Szczecińskiego

\title{
PRESENT AND FUTURE POSITION OF CREDIT RATING
}

Danuta Dziawgo, Prof.

Nicolaus Copernicus University

Faculty of Economic Sciences and Management

Department of Accounting

Gagarina 13a, 87-100 Toruń, Poland

e-mail:ddziawgo@umk.pl

Received 2 November 2012, Accepted 23 April 2013

\begin{abstract}
The aim of the elaboration is to draw attention to selected aspects of credit rating. For that reason, comparison and induction methods were used.

The article deals with credit rating and its present importance for the financial market. On that basis, possible scenarios for credit rating importance in the future will be analysed.

Nowadays, the credit rating system and credit rating agencies' behaviour and work quality are discussed worldwide. Therefore, the article can be seen as a voice in the discussion about future architecture of financial market and safety system net.
\end{abstract}

Keywords: credit rating, risk, global financial market.

JEL classification: F65, G15, G24, G38, G32. 


\section{Introduction}

After the first wave of financial crisis of 2007, we can now observe the second wave. The final results of the latest crisis are still unknown but this one is different from previous crises regarding the strong criticism concerning credit rating, especially from the politicians perspective. At present, credit rating is one of the standards in financial market functioning. It is commonly used as a tool for reducing investment risk, calculating the spread of debt instruments in the primary and secondary market and assessing the level of bankruptcy risk. Also, credit rating is present in investment regulations as a measure of investment safety. All these factors compose to the real importance of credit rating in the modern financial market.

Of course, credit rating agencies are not infallible. They have made mistakes. But in history, those agencies did not downgrade (or did not mention possibility of such downgrade) of the highest credit rating such economically and politically important countries as the United States of America, France or Germany. Therefore more and more often the question about the new financial order which will appear after the crisis is formulate.

But it seems, undoubtedly, that the new formula for credit rating will be implemented worldwide. In effect, credit rating will probably enter a new stage: a tool less used in law regulations and of less influence on the banking sector capital adequacy.

The aim of the elaboration is to draw attention to selected aspects of credit rating, especially from the macroeconomic point of view as an additional voice in current discussion.

For that reason, comparison, induction and case study methods were used.

Dealing with such currently discussed worldwide problem the article can be seen as a voice in discussion about future financial market structure and future position of credit rating in economy and financial market.

\section{Essence of credit rating}

In the modern global financial market investment safety is so significant. Due to the scope and diversity of risk in the international financial market there is a need for a universal measure of investment risk level which would allow to compare financial creditability of subjects from different national financial markets. The measure should not only be universal, but also cheap, fast and adequate.

Therefore, financial society is continuously searching for a tool to control and reduce the risk. One of such useful tools can be credit rating assessed to entities and, in a parallel manner, to instruments ${ }^{1}$. 
Credit rating can be defined as the system for estimate the investment risk. It is assessed by credit rating agencies and communicated to the market through simple letters code. From the investors' point of view, credit rating agencies are helpful because they assess the level of risk for investors, instead of them and even for free. Also important is the fact that credit rating agencies mitigate investment risk from the worldwide perspective. Therefore, credit rating is potentially a very useful tool but it does not exempt investors from their own risk estimation.

Credit rating is a fast and comparable measure describing relative risk of not meeting the time of obligation by issuers from the whole world. This relativity refers to credit rating as relative risk measure perceived in relation to other instruments. However, it should be noted that it is a subjective opinion of credit rating agencies on subject financial credibility or risk associated with securities investment ${ }^{2}$.

Therefore credit rating agencies play a crucial role in the global financial system as it is currently organised. This role is not limited to the elimination of an information asymmetry in favour of investors that readily take over advice provided by agencies in the form of credit rating, but actually extents to the fulfilment of a quasi-regulatory and thus public function in determining capital requirements for financial institutions, a crucial aspect of the prudential supervision and thus ultimately of financial stability as such. What is more, agencies do not only cast a judgment on the creditworthiness of companies, such as financial institutions and their financial products, but also on states. The current euro area crisis highlights the vast implications, whose a sovereign downgrading can have not only in the financial markets but also for the respective state itself ${ }^{3}$.

\section{Financial crisis 2007}

The financial crisis which began in 2006 is called 'sub-prime' as the instruments contributed to generating huge losses by banks. However, at the same time, sub-prime instruments were rated on the investment levels with the use of the same well-known symbols. Therefore, investors assumed that those instruments are characterized by low investment risk. Only when the crisis developed investors noticed that 'AA' rating of bonds and 'AA' ratings of asset-basedsecurities do not mean the same low risk level. Although the same symbols are used behind both instruments, there are different kinds of risk.

When interest rate increased on the market, creditors missed their timely payment of bigger instalment to banks. However, those credits were the base for other financial instruments called ABS (asset based securities) which were created during securitization process. When 
the wave of lack of credit repayment spread it resulted in the wave of ABS instrument credit rating downgrade. As an example it could be mentioned that in 2007 Fitch Ratings downgraded over 4.5 thousand sub-prime issues (77\% from the U.S.). In response, a great discussion in the press was initiated about credit rating agencies functioning and their role in misleading investors. It was also argued, that credit rating agencies did not understand the uniqueness of rated business, the specific features of rated institutions as well as rated instruments. Especially, that credit rating agencies lowered risk of instruments based on high-risk credits on which risk was transferred from banks into investors during securitization processes. Credit rating agencies were also blamed for manipulating investors through the use of the same letter codes for grading investment risk in different kinds of financial instruments.

At the same time, attention was drawn to asymmetric access to information. For estimating investment risk for bonds, investors could rely on many alternative sources of information. But in case of securitized products such an alternative to credit rating sources do not exist. In consequence, investors could not independently obtain key information for estimating the level of investment risk so they have to rely on credit rating agencies assessments. Therefore, the importance of credit rating is higher for securitized products than for classic bonds. Although, the first turbulences in sub-prime market began at the beginning of 2007, credit rating agencies decided not to downgrade until July. But then, the reduction was on the mass scale, and it deepened crisis of trust in the financial market. Investors interpreted that as a sign of coming soon a deep financial crisis.

Simultaneously, some practices of credit rating agencies behaviour have been publicized. Among others, they, at the same time, give credit rating and advise how instruments should be constructed for maximizing credit rating grade. It could result in a conflict of interest by giving grades expected by issuers who paid twice (for credit rating and for advice) but without respecting investors interest. In consequence, this could provide for intentionally credit rating overstatement (however, this cannot be easily proved).

Therefore, it could be concluded, that the financial crisis hit also credit rating agencies. Some argued that credit rating is worthless and the lack of transparency and supervision generates risk of the lack of trust between financial market participants. The role of credit rating agencies in sub-prime crisis should not be overestimated. They should not be blamed alone for creating and later on for the spread of crisis across the international financial market. Of course, at the same time, this role should not be underestimated. Credit rating agencies wasted capital of trust which they had been generating for decades. 
Lehman Brothers Holding Inc. is a well-known case of still the biggest bankruptcy in history. The assets of the number 4 investment bank were 640 billion USD (the previous bigger bankrupt 'only' 107 billion USD) and its own capital 30 billion USD (31.05.2008). Not repaid debt equalled nearly 145 billion USD (based on S\&P's data; according to Moody's data nearly 121 billion USD). To compare, the previous leader - WorldCom - did not repay 'only' 34 billion USD, and well-known Enron as 'little' as 14 billion USD.

In Table 1, the changes in credit rating made by Moody's Credit Ratings were compared. As it could be observed, agencies believed in bank management declarations that the bank would be taken over by another bank (media speculated that it could be Bank of America). In consequence, bankruptcy was announced at 'A2' grade by Moody's and 'A/A-1' from S\&P's.

Table 1. Calendar of Lehman Brothers Holdings credit rating changes given by Moody's Investors Service

\begin{tabular}{|c|c|l|}
\hline Data & Credit rating & \\
\hline 5.08 .1999 & A3 & credit rating increase from Baa1 \\
\hline 3.11 .2000 & A2 & credit rating increase \\
\hline 22.10 .2003 & A1 & credit rating increase \\
\hline 17.03 .2008 & A1 & confirmation A1, stable perspective \\
\hline 9.06 .2008 & A1 & negative perspective \\
\hline 13.06 .2008 & A1 & confirmation A1/Prime 1, place in watchlist - possibility of downgrade \\
\hline 17.07 .2008 & A2 & credit rating downgrade, negative perspective \\
\hline 10.09 .2008 & A2 & $\begin{array}{l}\text { A2 confirmation, watchlist - unknown future direction; } \\
\text { Reaction to the bank's information that for 3rd quarter of 2008, bank gained } \\
\text { loss nearly 4 billion USD due to reduction of real estate assets value by nearly } \\
\text { 8 billion USD }\end{array}$ \\
\hline 15.09 .2008 & B3/Non Prime & company go to court under bankruptcy law credit rating downgrade from A2 to B3 \\
\hline 8.12 .2008 & withdrawn & credit rating agency withdrew company from its credit rating list \\
\hline
\end{tabular}

Source: own, based on Moody's Investors Service materials.

Credit rating agencies behaviour can also be seen as ambiguous. AIG (American International Group) was rescued thanks to 40 billion USD loan from the Federal Reserve. Partially, that loan was given thanks to credit rating agencies. They announced that AIG liquidity was at a considerable risk. Therefore, they would downgrade AIG credit rating if by Monday it did not collect 40 billion USD. Federal Reserve board met at the weekend and granted AIG exactly that sum. But such an announcement could be viewed as a threat and pressure on sovereign countries and corporations. 


\section{Credit rating in regulations}

Credit rating is widely used in both regulations obligatory as well as facultative by Parliaments of individual countries, financial supervisions authorities, ministries of finance, and central banks. At the same time, credit rating is commonly used in self-regulations in a variety of subjects including investment funds, pension funds, and asset management companies. In their statute, they often include a given limit of speculative-rated financial instruments.

Regulations including credit rating can be divided into two main parts:

- creating extraordinary demand for credit rating (they have been functioning in the market since 1931), and

- regulating credit rating agencies activity (they have only been operating since the $21^{\text {st }}$ century, after a series of bankruptcies started by Enron).

As an example the first regulation ever based on credit rating can be quoted. It was stated by the Office of the Controller of the Currency in 1931. It obliged banks to invest in bonds with credit rating on 'BBB' or higher by at least one credit rating agency. Such securities could be accounted according to their accounting value. In other cases, the value should be lowered to its market value (when market value was lower than accounting value) and additionally, banks were obliged to make reserve at $50 \%$ of that difference. In 1936, that regulation was restricted to rated securities by two agencies instead of one ${ }^{4}$. That regulation was in power to 1989 when U.S. Congress changed the number of agencies again from two to one ${ }^{5}$.

Undoubtedly, the most important regulations are those related to banking sector. In the so-called Basel II regulations about the adequate level of capital, the way of system risk wages in credit risk is based in general on individual credibility of client assessment. It is estimated by the bank decision on the basis of:

- credit ratings assigned by credit rating agencies, or

- own ratings ( IRB $^{6}$ ) assessed by banks using procedures approved by country's financial supervision authority.

In the beginning, it was stated that Basel II priority was to strengthen the stability of worldwide banking system as well as safety through better management of credit risk in banks. Even though the aim is noble, its detailed solutions - not necessarily. It is legitimate to ask the question whether the risk weight of $1.250 \%$ for $\mathrm{ABS}$ did not affect the increase of 2007 crisis results?

Besides, what protects a single bank cannot protect the whole banking system. If all banks measure risk according to the same instruction and model, modified only in details, commonly 
viewed as adequate, appropriate and accepted by banking supervision across countries, then it can result in bigger impact to the whole financial system of some information, unexpected events, changes in opinions and prognosis. As an example, some evidence for VaR can be quoted - common use of the VaR model decreases assets prices, increases the level of their volatility and increases amplitude and reaction period of asset prices to shocks ${ }^{7}$. Until now, it has not been proved that proposed quantitative models represent 'better risk management' Unification in measuring such a complex thing as risk can be destructive for the system as a whole because it will trigger a standardized reaction adjusted to model needs.

Constructions of the I pillar will result in the rise of regulating the capital of given portfolio during crisis and in its decrease during the economy growth. In effect, it may result in the increase of fluctuation of economic cycles $^{8}$. Simulation results indicate that capital may increase during downturn in economy by even $40 \%{ }^{9}$. Now we are just facing it.

Also, it should be pointed out that two banks with the same level of bankruptcy risk but different size exposure generate equal risk for depositors but different risk for the whole international financial system. Unfortunately, in Basel II such a problem was not addressed ${ }^{10}$. Also, individual banks may have satisfying liquidity which means that they meet the capital regulatory criteria, but the level could not be enough for the whole system, at a given time.

We can agree with Monfort and Mulder that for the regulatory requirements in banks credit rating should not be used in such a wide scope, because:

- their adequacy during crises was not positively verified,

- they measure risk of bankruptcy, the risk of timely payment and not the level of possible unexpected losses,

- they are pro-cyclical because they react asymmetrically - credit ratings decrease after a crisis begins but they remain at that low level long during the economy recovery ${ }^{11}$.

We could also agree with Ward arguments that all three pillars of new capital adequacy concept are based on an assumption that capital market is effective ${ }^{12}$. However, there is no evidence that in all the countries capital market is fully effective. Also, the question how far it should be effective to be enough for banks during the recession time and for banking system to be viewed by deponents as stable and safe, still remains open.

Unfortunately, the above mentioned arguments as well as other arguments formulated by academics have been ignored. 


\section{Present position of credit rating}

As it has been described earlier, the present position of credit rating is very powerful. It is so crucial in and for financial market especially due to several factors.

1. Credit rating is present in the investment regulations for financial institutions.

2. Credit rating is present in the capital adequacy regulations for banking sector.

3. Credit rating industry has oligopoly structure consisting of three American credit rating agencies, dominating on that market (around 80\%).

4. Neither credit rating agencies nor credit rating analysts are responsible for their analyses or opinions.

5. Credit rating agencies cover thousands of issuers and instruments.

6. Credit rating agencies help investors in decision making process without being paid by investors.

7. Investors calculate profitability as spread based on credit rating current level.

8. Credit rating is a simple code, understandable even by people without economic knowledge.

9. Credit rating helps communicate the investment risk level by limiting the story to a few words, like 'triple a' or 'double b plus'.

10. Credit rating is commonly use worldwide.

In practice, credit rating evolved significantly since its beginnings i.e. supporting opinion for investors on investment risk. At present, such elements were based on credit rating as risk management in banks, stability and security of banking system as well as security of contemporary financial market. In a sense, financial supervision was commercialized - it was handed to private-owned subjects without a possibility of evaluating them for their work quality. Credit rating agencies do not take any responsibility for assessment given by them contrary to other subjects which risk money such as commercial banks, insurance companies, pension funds or investment funds. However, their influence on financial market is unquestionable.

For many years in the financial market a peculiar game on risk has been taking place, between credit rating agencies on the one side, politicians (governments, parliaments, supervision authority) on the second side and financial market (investors, issuers, analysts, media) on the third side. Also today, such as game is taking place - it simply entered another stage. Observing that generates a question about realized priority: is it investors' safety - as it is commonly declared and whenever it has ever been a priority. 
However, perhaps there are other priorities functioning in reality, which are not publicly declared? If yes, we have to ask a question: which ones? I encourage to discuss and identify them.

It seems, that politicians could realize a bunch of goals and, depending on current needs, specific goals change into priority.

1. Comfortable supervision on financial market.

2. Confirmation of high quality of governing the country (AAA) in voters eyes.

3. Confirmation of world economy leader position.

4. Confirmation that economy policy is appropriate (including fiscal and monetary policy).

5. Privilege position in issuers thanks to risk-free status in regulations.

6. Privilege position in financial investors thanks to regulations which oblige them to invest in risk-free instruments (directly: to create a wide investors base for securities issues; indirectly: to increase securities liquidity).

7. Lower cost of gaining capital from the financial market.

8. Certainty of success in new securities issues.

9. Reduction of the currency exchange volatility.

Politicians seem to use credit rating instrumentally. The issuer's point of view dominates. Credit rating is useful to:

- widen investors base,

- reduce competition from other subjects (countries, corporations, banks).

In effect, they reduce cost of financing current deficit and they make credit rating easier and longer life on future generations' cost.

In consequence, credit rating will be good for politicians until its country will be privileged. Otherwise, credit rating will not be needed as it no longer guarantees a privileged position.

One should also raise a question about the investors' role in that game - or even more widely - financial market participants. Do they only passively react to credit rating changes or maybe they try actively influence credit rating through market behaviour?

The latest financial market observations clearly show that especially the investors' group is significantly active. The Euro-zone credit rating downgrade happened after bonds rate on the market increased and remained on that high level for several weeks. Therefore, it was the investors who first said 'stop' for continuous increase of the level of counties' debt, and not credit rating agencies.

It was the investors who boycotted the German government new issues of debt securities to push politicians to take active, on a massive scale, action by the European Central Bank. 
Also, it should be noticed that after that expected intervention investors accepted it by lowering market euro-bond treasury rate on the secondary market, as well as on primary market.

In history, such investors activities were not as clear as nowadays. Also their action was, undoubtedly, coordinated. This can be seen as a new phenomenon.

\section{Future position of credit rating}

It seems that modern financial market aims at an increase of complexity of financial products offered. Therefore, investment in those instruments will be connected with a higher level of investment risk. In consequence, on the financial market will increase demand for investment risk measures - simple, quick, cheap, complex, covering wide range of instruments and issuers. Those features are, undoubtedly, met by credit rating.

However, credit rating also has to fulfil a reliability condition. This is a very important challenge for credit rating agencies.

In the financial market, until now, has not been invented a better instrument for making easier investment decisions. Although, investors as well as regulators and supervision authorities use that instrument for overmuch exempt from responsibility.

Credit rating undoubtedly is a wonderful invention which facilitates investing in the financial market. It is beyond and doubt that credit rating is a useful tool to control and reduce a risk during the investment process in the financial market. But, at the same time, credit rating itself influences financial market and is stimulated by financial market.

One should pay attention to a peculiar game which is now taking place between the financial market and politicians. However, in the game credit rating agencies are not participating - this time they are just observers, and the committed mistakes ${ }^{13}$ additionally depreciate them and they quicken achieving consensus concerning their future role in the financial market in the eyes of politicians and financial supervisions. In this way, the future architecture of financial market and its supervision is now created. It seems that the interest of both politicians and market is the weakening of credit rating agencies but not their elimination. However, such a solution cannot be eliminated. Several possible scenarios can be formulated.

1. Scenario of increasing credit rating application in legal regulations.

2. Scenario of maintaining status quo.

3. Scenario of eliminating credit rating from all legal regulations.

4. Scenario of significant reduction of credit rating application in legal regulations.

At present, the least probable seem scenario $1 \& 2$. 
On the basis of the presented facts and speculations it seems justified to pose a questions: where is credit rating aiming? That question should be preceded by an attempt to find out what happened that the criticism addressed at credit rating agencies became severe. It seems that in that issue an attention should be drawn to several aspects.

In the chronological perspective, it seems that credit rating functioned relatively properly until the time of sudden increase of international debt market. The rise of the number of subjects from various sectors, as well as the number and value of their issues, certainly influence the necessity of more careful and more often monitoring in the scope of grades adequacy. Nevertheless, it requires higher operating cost of credit rating agencies which, in turn, does not meet the profit maximalization strategy. Obviously, the ability to generate income will be lowered in the case of decreasing the reputations on the market when inadequate agencies grades are given. However, when oligopoly of three agencies is maintained and at the same time there is a need for using credit rating resulting from legal regulations such a risk does not seem that serious to weaken agencies financial results for longer than two years. Such expectations may lead to moral hazard in all the three credit rating agencies which for many years where mentioned as the only ones in legal regulations of many countries, including the U.S.

Moreover, on the market more and more complex financial instruments such as ABS started to be issued. Due to legal regulations, in order to find buyers they had to have credit rating at the investment level. It seems that for maximizing profit, credit rating agencies adjusted their methodology and system of ratings to needs quoted by the market. The previous consideration about moral hazards are also adequate in this case.

It should not be left unnoticed, that relying state supervision safety of banking sector regulation and handing it to commercial credit rating agencies assessment resulted in externalization of state supervision. Such activities cause moving supervision cost from state bodies to the very supervised subjects, subjects issuing debt securities, and credit rating agencies. At the same time, in the case of mistakes, supervisions in individual countries will easily name the guilty banks and credit rating agencies; banks because they wrongly constructed their portfolio and assessed risk, and credit rating agencies which wrongly assessed risk. At present, we are witnessing such a shift of the blame onto others.

The attention should also be paid to the fact, that credit rating agencies stop tolerate welldeveloped countries excesses and start, as a teacher, reprimand governments of those countries which previously taught others; such as the United States, France and the European Monetary Union. This provoked a quick and sharp reaction from those countries by financial supervision activities and activated law regulations changes. 
The question: 'Whose problem is credit rating?' still remains valid.

Politicians found themselves evaluated and in the compromises which they make they have to take into consideration their potential impact of credit rating on other countries and their own countries. As an example, the banks' 'voluntary' agreement for 50\% reduction of Greece debt can be quoted here. During negotiations process many times was quoted a question about the potential effect to credit rating level of: Greece, banks participating in agreements, but also France, Germany, and European Financial Stability Facility.

Credit rating agencies reprimand individual countries to pay attention to introduce reforms, reduce deficit, and reduce public debt. Agencies announce a possible downgrade (threats) or made such a downgrade. As an example the United States, France, Italy, Spain or the European Financial Stability Facility could be mentioned.

Issuers pay for credit rating assessed to them and then for monitoring a significant amount of money. Withdrawing credit rating from law regulations will probably reduce issuers' demand for credit rating because credit rating will no longer widen the potential investors scope. The cost reduction of new issues resulting from not obtaining credit rating will be beneficial for issuers. Unfortunately, the question is whether risk assessment avoidance will not increase the cost of gaining capital from the financial market. Such a scenario seems probable. Less known subjects could be thrown out from the financial market or would collect capital at much higher costs.

Investors, without information about risk associated with a given investment will be pushed to make themselves many more analyses and in a wider scope than today - part of these analyses will generate additional cost due to developing departments dealing with the analyses. This will increase the cost of investing on the financial market. Certainly, investors may buy external analyses, but this also will generate additional cost. So, a given amount of money saved by a single issuer can nevertheless be spent by investors. Due to the fact that many investors are active in the market the money will be multiplied. In consequence, globally, the saved money will be lower than spend money when shifting it between group of payers. Another result obtained will probably be a higher information asymmetry on the financial market.

It should also be commented the issue if credit rating is not a problem of credit rating agencies themselves. Some previous behaviour of the agencies indicated carelessness during the rating assessment, especially concerning instruments such as ABS type. It seems that the agencies' legal privileges which have been broadened (e.g. Basel II) exponentiate moral hazard behaviour. Agencies fall into a trap which they partially set themselves as they supported financial institutions in the securitization game. 
It seemed that this crisis will more or less the same as the previous crises - a few subjects will go bankrupt, a few investors will lose, media and investors will complain on credit rating agencies and on their work quality but then will conclude that nevertheless credit rating agencies activity is beneficial for functioning and continuous development of financial market.

But this time it is different. This crisis is different from the previous ones in its scale and infection of countries which were perceived as world economy pillars and guarantees of its stable development. Therefore, it can be forecast that this crisis will affect the future position of credit rating agencies. Probably, their privilege position in law regulations will be eliminated - but not in one year. Nowadays, the priority is to reduce the financial crisis, and credit rating can be useful in that process.

Probably, the position of credit rating agencies in economy will evolve to companies which deal with risk assessment, still be paid by issuers and still their products will be available to investors for free (only more detailed and specific analyses will be paid by investors). But they will be a common commercial company, without being mentioned in regulations concerning investment safety, which will compete about clients on a more competitive market. The diversity of opinions will cause some information chaos but it will not be treated as a huge disadvantage by investors. The diversity of opinions on an issue as hard to quantify as risk is desired and makes value added.

We also take into consideration, that undoubtedly, the construction of financial instruments is undergoing complex changes, therefore each purchase or issue of a given financial instrument should be considered individually in detail and not schematically ${ }^{14}$.

\section{Conclusions}

The basic condition for credit rating existence is investors' trust. Without that trust issuers will not order credit rating. In consequence, inappropriate rating can result in market share loss for a given agency. If many agencies operate in the market then market itself will verify credit rating usefulness (with professionalism and objectivism) through a level of demand for different agencies services. The problem is when the market is dominated by three companies.

One should be aware that investors still use credit rating in practice due to several reasons:

- lack of alternatives for measuring creditability of subjects and financial instruments on such a wide scope,

- law regulations creating demand for credit ratings, 
- investors getting accustomed to free grades as well as to free financial auditor statements.

Due to the daily use of credit rating in the process of investing on the market and due to credit rating implementation in regulations related to investment safety in the market credit rating is used as routine and without any criticism. However, credit rating is not a perfect tool and the circumstances in which it exists are not perfect. We have to take it into consider. At the same time, the imperfections influence both investors as well issuers (from microeconomic perspective), and also whole economy (from macroeconomic perspective).

Therefore, credit rating is a tool to reduce investment risk, and at the same time it generates additional risk.

If the system which is now functioning is supposed to be dismantled or significantly changed something should be proposed instead of. The crisis cannot be the best moment for radical changes on the one hand but on the other hand it encourages to make changes, even deeper and more radical ones.

\section{Notes}

1 Dziawgo (2011).

2 Dziawgo, D. (2010).

3 Haan, Amtenbrink (2011).

4 Cantor, Packer (1995). In 1936 on the NYSE 891out of 1,975 bonds were rated lower than 'BBB'.

5 Congressional...

6 IRB - Internal Ratings Based approach (use in Basel II capital adequacy regulations.

Danielsson, Shin, Zigrand (2002).

8 Ward (2002).

9 Monfort, Mulder (2000); Estrella (2000).

${ }^{10}$ Ward (2002).

${ }^{11}$ Credit ratings... (2000); Altman, Saunders (2000). Credit ratings downgrade is strongly correlated with the phase of economy cycle.

12 Ward (2002).

${ }^{13}$ As an example can be mentioned information about France downgrade, which did not happen at that moment (but after a few months).

${ }^{14}$ Dziawgo, L. (2010), p. 181. 


\section{References}

Altman, E. \& Saunders, A. (2000). An Analysis and Critique of the BIS Proposal on Capital Adequacy and Ratings, January, www.stern.nyu.edu/-ealtman/bis.pdf.

Cantor, R. \& Packer, F. (1995), The Credit-Rating Industry. The Journal of Fixed Income, December.

Congressional Promulgation of the Financial Institutions Recovery and Reform Act of 1989, United States Securities and Exchange Commission.

Credit ratings and complimentary sources of credit quality information (2000). A. Estrella (Ed.), BCBS Working Paper No. 3, August.

Danielsson, J., Shin, H.S. \& Zigrand, J.-P. (2002). The impact of risk regulation on price dynamics. London Stock Exchange, London: FMG.

Dziawgo, D. (2010). Credit rating na rynku finansowym. Warsaw: PWE.

Dziawgo, L. (2010). Zielony rynek finansowy. Ekologiczna ewolucja rynku finansowego. Warsaw: PWE.

Dziawgo, L. (2011). Współczesny biznes bankowy - patologiczne otoczenie, „ekonomia polityczna" oraz ład monetarno-instytucjonalny rynku finansowego jako zagrożenie dla bankowości. Bezpieczny Bank No. 3.

de Haan, J., Amtenbrink, F. (2011). Credit rating agencies. DNB Working Paper No. 278.

Monfort, B. \& Mulder, C. (2000). Using credit-ratings for capital requirements on lending to emerging market economies: possible impact of a new Basel Accord. IMF Working Paper No. WP/00/69.

Moody's Investors Service materials.

Ward, J. (2002). The New Basel Accord and Developing Countries: Problems and Alternatives. Working Paper No. 4, Cambridge University, Cambridge. 